\title{
Wastes released by tanneries at Patrocínio Paulista, São Paulo State, Brazil
}

\author{
D. M. Bonotto, J. R. Jiménez-Rueda, H. F. Palermo \\ \& L. Caprioglio \\ Departamento de Petrologia e Metalogenia, \\ Instituto de Geociências e Ciências Exatas-UNESP, Brazil
}

\begin{abstract}
This investigation was carried out within the Paraná sedimentary basin, Brazil, and involved the sampling of sludge and residuary waters that were collected from reservoirs/decantation ponds settled in two tanneries situated at Patrocínio Paulista, São Paulo State. Two samples from each tannery were collected, stored in appropriate flasks and transported to the LABIDRO for chemical analysis. The LABIDRO (Laboratory of Isotopes and Hydrochemistry) of the Petrology Department at the Geosciences and Exacts Sciences Institute of UNESP is situated in Rio Claro city, about $240 \mathrm{~km}$ distant from the investigated area. The data for residuary waters were compared with guideline values established by two different legislations: (a) Rule No. 12486 (NTA60) established in $20^{\text {th }}$ October 1978 by São Paulo State for defining the potable water standards and (b) Register 997 published on 31 May 1976 that defines the permissible concentration limits in effluents to be released to water bodies (coastal, fresh or ground waters) in São Paulo State. The results confirmed that leather production is an activity with high environmental impact, despite improvements that may be achieved by tanneries.
\end{abstract}

Keywords: leather, tanneries, sludge, residuary waters, São Paulo State, Brazil.

\section{Introduction}

São Paulo is the most populous Brazilian state, comprising 40 million inhabitants distributed over 645 municipalities. It has the highest number of industries and economic production, reaching 31\% of the Brazilian GDP-gross domestic product. Despite the vigorous industrial production that includes high 
technology goods, the state also is well developed in agriculture and cattle breeding [1]. This advanced stage of agricultural and industrial growth causes to São Paulo State a great diversity of problems related to the interaction between the society and the environment.

The cattle breeding at São Paulo State is an important economic activity, as the number reaches 12.6 million, the $5^{\text {th }}$ in Brazil. However, in terms of exportation, $70 \%$ of the Brazilian meat leaves São Paulo State through Santos harbor. The state contributes with about 2 billion liters of milk per year that represents $\sim 10 \%$ of the Brazilian milk production, but despite this São Paulo State is the main center consuming dairy products in the country $[2,3]$.

The term hide has been used to designate the skin of larger animals (e.g., cowhide or horsehide), whereas "skin" refers to that of smaller animals (e.g., calfskin or kidskin) [4]. The preservation process employed is a chemical treatment called tanning, which converts the otherwise perishable skin to a stable and non decaying material [4]. Although the skins of such diverse animals as ostrich, lizard, eel, and kangaroo have been used, the more common leathers come from cattle [4]. Thus, leather is a durable and flexible material created via the tanning of a putrescible animal rawhide and skin, primarily cattle hide.

The production of leather by cattle hide is an important economic activity in Brazil that is the $5^{\text {th }}$ in world after USA, Russia, India and Argentine [5]. The Brazilian worldwide leather production corresponds to $10-11 \%$ and São Paulo State is the major exporter (33.1\% of the national production) [5]. The number of tanneries in Brazil is about 450 and most of them (80\%) employ between 20 and 99 laborers each. In the year 2006, it was processed around 45 million leather pieces, and the exportation of 34 million yielded an income of US\$ 1.87 billion [5].

Leather can be produced through different manufacturing processes, ranging from cottage industry to heavy industry. In the leather industry, the skin and rawhide are bi-products of the meat industry, because the meat has greater commercial value than the rawhide and skin. The leather manufacturing process is divided into three fundamental sub-processes: preparatory stages, tanning and crusting [6].

The preparatory stages are when the hide/skin is prepared for tanning. Preparatory stages may include: preservation, soaking, liming, un-hairing, fleshing, splitting, re-liming, de-liming, bating, degreasing, frizing, bleaching, pickling and de-pickling [6].

Tanning is the process which converts the protein of the raw hide or skin into a stable material which will not putrefy and is suitable for a wide variety of end applications. The principal difference between raw hides and tanned hides is that raw hides dry out to form a hard inflexible material that when re-wetted (or wetted back) putrefy, while tanned material dries out to a flexible form that does not become putrid when wetted back [6]. There are a large number of different tanning methods and materials that can be used; the choice is ultimately dependent on the end application of the leather. The most commonly used tanning material is chromium, which leaves the leather once tanned a pale blue color (due to the chromium); this product is commonly called "wet blue" [7]. 
The process was invented in 1858 and involves the use of chromium sulfate or other salts of chromium. The hides once they have finished pickling will typically be between $\mathrm{pH}$ of 2.8-3.2 [7]. At this point the hides would be loaded in a drum and immersed in a float containing the tanning liquor [6].

Crusting is when the hide/skin is thinned, retanned and lubricated. Often, a coloring operation is included in the crusting sub-process. The chemicals added during crusting have to be fixed in place. The culmination of the crusting subprocess is the drying and softening operations [6].

Because of the various steps involved on the leather production, such an activity exhibits high environmental impact, most notably due to: the impact of livestock, the heavy use of polluting chemicals in the tanning process and the air pollution due to the transformation process (hydrogen sulfide during de-hairing and ammonia during de-liming, solvent vapors). One tonne of hide or skin generally leads to the production of 20 to $80 \mathrm{~m}^{3}$ of turbid and foul-smelling wastewater including chromium levels of 100-400 mg/L, sulfide levels of 200 $800 \mathrm{mg} / \mathrm{L}$ and high levels of fat and other solid wastes, as well as notable pathogen contamination [8]. Pesticides are also often added for hide conservation during transport. With solid wastes representing up to $70 \%$ of the wet weight of the original hides, the tanning process comes at a considerable strain on water treatment installations [8].

This paper describes the results of chemical analyses performed in effluents generated by tanneries installed at Patrocínio Paulista, São Paulo State, Brazil, where the leather production involving cattle hide has been conducted for many years. The data will be evaluated considering the possibility of the wastes utilization for increasing the soil productivity, as it has been often reported by some investigators in Brazil.

\section{General features of the area studied}

The study area is situated in the municipality of Patrocínio Paulista that is about $410 \mathrm{~km}$ distant from São Paulo city, the capital of São Paulo State. It is located at $20^{\circ} 37^{\prime} 48^{\prime \prime} \mathrm{S}$ and $47^{\circ} 16^{\prime} 48^{\prime \prime} \mathrm{W}$ (Fig. 1), the altitude is $800 \mathrm{~m}$ above sea level, the surface area of the city is $\sim 610 \mathrm{~km}^{2}$, the population is $\sim 12,000$ inhabitants, and the cerrado fields dominate the landscape of the region [10]. The major economic activities of the municipality involve the agro business, with dominance of coffee and sugarcane production [10]. There is also a large number of tanneries (about 300) settled in the municipality that are extensively involved in the leather production

The area is geologically situated at the giant Paraná sedimentary basin that extends over an area of 1.7 million $\mathrm{km}^{2}$ (1 million $\mathrm{km}^{2}$ in Brazilian surface) [11]. Some of these stratigraphic units of the Paraná basin (Paleozoic - Cenozoic) crop-out in it (Fig. 1): the Tubarão Group comprising the Itararé Subgroup (sandstones, conglomerates, diamictites, tillites, siltstones, shales and rythmites) and Tatuí Formation (siltstones, shales, silex and sandstones with local concretions); the Passa Dois Group comprising the Irati Formation (siltstones, mudstones, black betuminous shales and limestones) and Corumbataí Formation 


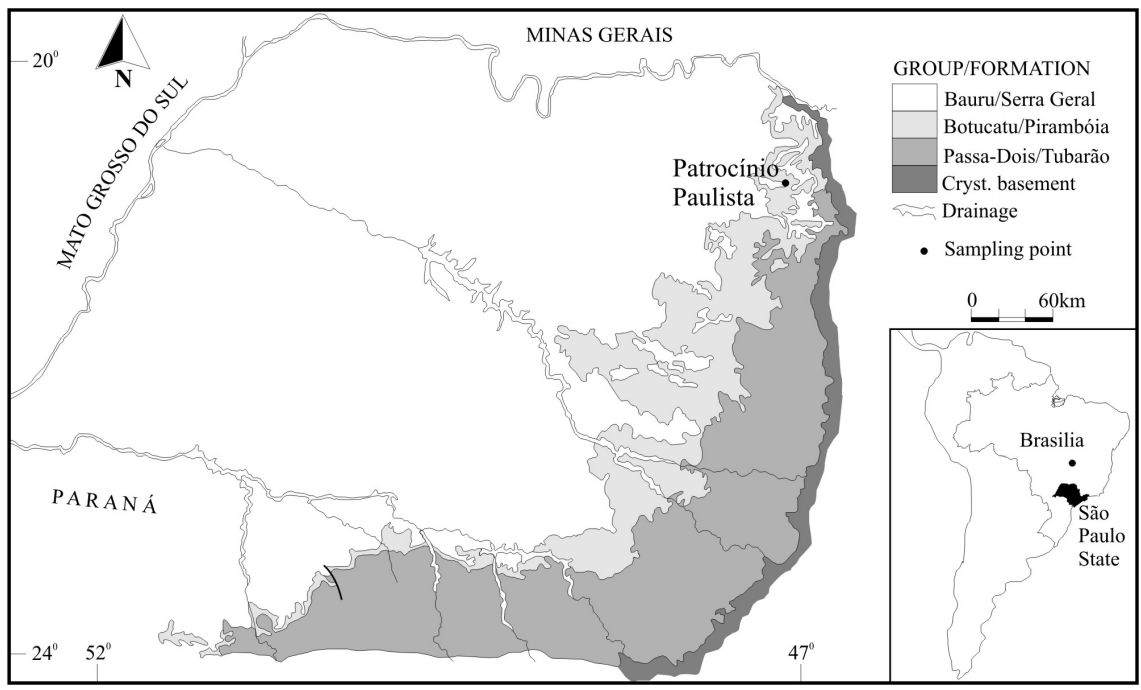

Figure 1: A simplified geological map of São Paulo State, Brazil, and location of the sampling point for chemical analyses of tannery wastes. Modified from [9].

(mudstones, shales and siltstones); the São Bento Group comprising the Pirambóia Formation (sandstones, shales and muddy sandstones), Botucatu Formation (sandstones and muddy sandstones), Serra Geral Formation (basalts and diabases) and related basic intrusives; different types of Cenozoic covers like the recent deposits, terrace sediments and others formations comprising sandstones, conglomerate sandstones, muddy sandstones, etc.

\section{Material and methods}

This study provided chemical data for samples of sludge and residuary waters collected at reservoirs/decantation ponds settled in two tanneries situated at Patrocínio Paulista city: Finipelli and CURVASA. Two samples from each tannery were collected, stored in appropriate flasks and transported to LABIDRO for chemical analysis. LABIDRO (Laboratory of Isotopes and Hydrochemistry) of Petrology Department from Geosciences and Exacts Sciences Institute that belongs to UNESP is situated at Rio Claro city, about $240 \mathrm{~km}$ distant from the investigated area.

The sludge samples were dried at $60^{\circ} \mathrm{C}$, one 10 g-aliquot was taken for evaluating moisture and other aliquots of variable weigh were separated for different chemical analyses. Such aliquots were inserted in distilled water or digested with different acids, depending on the requirements of the analyses. The total organic matter content was evaluated by spectrophotometry [12] held in a solution obtained after adding potassium dichromate and sulfuric acid to $1 \mathrm{~g}$ aliquot; organic carbon was oxidized to carbon dioxide with a parallel reduction 
of hexavalent chromium to trivalent chromium and an accompanying color change from orange to green read at $610 \mathrm{~nm}$ [12]. The organic carbon was estimated from those readings by the Walkley-Black method [13].

Several standard analytical techniques were used for obtaining others parameters analyzed in the sludge samples, for example, methyl orange endpoint titration, potentiometry, ion selective electrode, and spectrophotometry. A portable meter was used for $\mathrm{pH}$ determination that was performed by a digital portable meter coupled to a combination glass electrode; buffer solutions equilibrated with the sample temperature were utilized to calibrate the equipment before the analyses. The bicarbonate concentration was determined by titration using a titrator with sulfuric acid standard solution to an end point evidenced by the color change of a standard indicator solution [14].

Calcium hardness (as $\mathrm{CaCO}_{3}$ ) and magnesium hardness (as $\mathrm{MgCO}_{3}$ ) of the samples were determined by the colorimetric method (wavelength $522 \mathrm{~nm}$ ) after chelating calcium with EGTA and calcium and magnesium with EDTA [12], parameters that allowed to evaluate $\mathrm{Ca}$ and $\mathrm{Mg}$ contents. The analyses of sodium

Table 1: Results of the chemical analysis for sludge samples collected at Finipelli tannery in Patrocínio Paulista, São Paulo State, Brazil.

\begin{tabular}{cccc}
\hline PARAMETER & UNIT & SAMPLE 1 & SAMPLE 2 \\
\hline Date of sampling & - & October 1997 & June 2000 \\
Moisture & $\%$ & 84.6 & 82.4 \\
Total Solids & $\mathrm{ppm}$ & - & 578,210 \\
Volatile Solids & $\mathrm{ppm}$ & - & 33,100 \\
pH & - & 7.5 & 8.1 \\
Organic Matter & $\%$ & 8.6 & - \\
Organic Carbon & $\%$ & 4.0 & 41.2 \\
N-total & $\mathrm{ppm}$ & - & 70,928 \\
N-ammonium & $\mathrm{ppm}$ & - & 14,077 \\
N-nitrate & $\mathrm{ppm}$ & 1,320 & 7,941 \\
N-nitrite & $\mathrm{ppm}$ & - & 107 \\
P-total & $\mathrm{ppm}$ & - & 2,104 \\
Bicarbonate & $\mathrm{ppm}$ & 56,000 & - \\
Sulfate & $\mathrm{ppm}$ & 12,200 & - \\
Chloride & $\mathrm{ppm}$ & 410 & - \\
Fluoride & $\mathrm{ppm}$ & 2,000 & - \\
Sodium & $\mathrm{ppm}$ & 116,800 & 72,191 \\
Potassium & $\mathrm{ppm}$ & 6,620 & 18,373 \\
Calcium & $\mathrm{ppm}$ & 40 & 361 \\
Magnesium & $\mathrm{ppm}$ & - & 650 \\
Aluminum & $\mathrm{ppm}$ & 2,880 & - \\
Zinc & $\mathrm{ppm}$ & 90 & - \\
Titanium & $\mathrm{ppm}$ & $<1.0$ & - \\
Chromium & $\mathrm{ppm}$ & 10,800 & 1,805 \\
\hline
\end{tabular}


were done by flame photometry, whereas potassium was determined by the tetraphenylborate method that is based on the combination of $\mathrm{K}$ with sodium tetraphenylborate to form an insoluble white solid read at $650 \mathrm{~nm}$ [12].

Chloride and fluoride were measured potentiometrically after adding a known amount of ionic strength adjustor to each sample, when necessary. Orion ionselective electrodes coupled into a digital meter were used, where standards containing variable concentrations of chloride and fluoride were utilized for preparing calibration curves consisting on logarithmic straight lines involving the potential and concentration readings. Nitrate, nitrite, ammonium, phosphorus and sulfate were determined by colorimetry [12] after adding reagents to the samples that are able to produce colored complexes read by a program stored in Hach $\mathrm{DR} / 2000$ spectrophotometer previously calibrated in variable concentrations at different wavelengths.

The metals $\mathrm{Al}, \mathrm{Zn}$ and $\mathrm{Cr}$ were also measured colorimetrically. The eriochrome cyanide $\mathrm{R}$ combines with aluminum in the sample to produce an orange-red color read at $535 \mathrm{~nm}$. The zincon method [12] was utilized for measuring zinc that is read at $620 \mathrm{~nm}$, whereas the 1,5-diphenylcarbohydrazide method [12] allowed determine the total chromium that is read at $540 \mathrm{~nm}$.

The samples of residuary waters were analyzed by the same methods utilized for sludge, except in the case of the metals that were quantified by atomic absorption spectrophotometry and inductively-coupled plasma spectrometry rather than colorimetry.

Table 2: $\quad$ Results of the chemical analysis for samples of residuary waters collected at CURVASA tannery in Patrocínio Paulista, São Paulo State, Brazil.

\begin{tabular}{cccc}
\hline PARAMETER & UNIT & SAMPLE 1 & SAMPLE 2 \\
\hline Date of sampling & - & February 1996 & April 1996 \\
pH & - & 7.7 & 7.7 \\
Organic Matter & $\%$ & 5.7 & n.m. ${ }^{*}$ \\
Organic Carbon & $\%$ & 3.3 & n.m. \\
Sodium & $\mathrm{mg} / \mathrm{L}$ & 2,000 & 187 \\
Potassium & $\mathrm{mg} / \mathrm{L}$ & 100 & 10.8 \\
Calcium & $\mathrm{mg} / \mathrm{L}$ & 1,300 & 211 \\
Magnesium & $\mathrm{mg} / \mathrm{L}$ & 100 & 27.5 \\
Chloride & $\mathrm{mg} / \mathrm{L}$ & 3,640 & 1,559 \\
Bicarbonate & $\mathrm{mg} / \mathrm{L}$ & 420 & 15.5 \\
Nitrate & $\mathrm{mg} / \mathrm{L}$ & 0.40 & 3.52 \\
Sulfate & $\mathrm{mg} / \mathrm{L}$ & 3,200 & 700 \\
Fluoride & $\mathrm{mg} / \mathrm{L}$ & 21.9 & 0.19 \\
Aluminum & $\mathrm{mg} / \mathrm{L}$ & 800 & 1.3 \\
Zinc & $\mathrm{mg} / \mathrm{L}$ & 10 & 0.2 \\
Titanium & $\mathrm{mg} / \mathrm{L}$ & 10 & $<0.002$ \\
Chromium & $\mathrm{mg} / \mathrm{L}$ & 200 & 12.1 \\
\hline
\end{tabular}

n.m. $=$ not measured. 
Table 3: $\quad$ Parameters established by Rule No. 12486 (NTA60) published on $20^{\text {th }}$ October 1978 by São Paulo State.

\begin{tabular}{|c|c|c|}
\hline PARAMETER & UNIT & VALUE \\
\hline Color & Pt-Co & $10-20 \mathrm{mg} / \mathrm{L}$ \\
\hline Odor & - & Absent \\
\hline Turbidity & NTU & $2-5$ \\
\hline Dry Residue & $\mathrm{mg} / \mathrm{L}$ & $<500$ \\
\hline $\mathrm{pH}$ & - & from 5 to 9 \\
\hline Aspect & - & Limpid \\
\hline Consumed Oxygen & $\mathrm{mg} / \mathrm{L}$ & $<2.5$ \\
\hline Residual Chlorine & $\mathrm{mg} / \mathrm{L}$ & $<0.3$ \\
\hline Nitrate & $\mathrm{mg} / \mathrm{L}$ & $<10$ \\
\hline Chloride & $\mathrm{mg} / \mathrm{L}$ & $<250$ \\
\hline Fluoride & $\mathrm{mg} / \mathrm{L}$ & $<1$ \\
\hline Sulfate & $\mathrm{mg} / \mathrm{L}$ & $<250$ \\
\hline Arsenic & $\mathrm{mg} / \mathrm{L}$ & $<0.05$ \\
\hline Barium & $\mathrm{mg} / \mathrm{L}$ & $<1$ \\
\hline Cadmium & $\mathrm{mg} / \mathrm{L}$ & $<0.01$ \\
\hline Lead & $\mathrm{mg} / \mathrm{L}$ & $<0.05$ \\
\hline Cyanide & $\mathrm{mg} / \mathrm{L}$ & $<0.2$ \\
\hline Copper & $\mathrm{mg} / \mathrm{L}$ & $<1$ \\
\hline Hexavalent chromium & $\mathrm{mg} / \mathrm{L}$ & $<0.05$ \\
\hline Mercury & $\mathrm{mg} / \mathrm{L}$ & - \\
\hline Total iron & $\mathrm{mg} / \mathrm{L}$ & $<0.3$ \\
\hline Manganese & $\mathrm{mg} / \mathrm{L}$ & $<0.05$ \\
\hline Selenium & $\mathrm{mg} / \mathrm{L}$ & $<0.01$ \\
\hline Zinc & $\mathrm{mg} / \mathrm{L}$ & $<5$ \\
\hline Total Coliforms & $\mathrm{n} / 100 \mathrm{~mL}$ & Absent \\
\hline Total Solids & $\mathrm{mg} / \mathrm{L}$ & $<500$ \\
\hline
\end{tabular}

\section{Results and discussion}

The results for the analyses of sludge samples are reported in Table 1. Sample 1 is enriched in several compounds inclusive chromium, as expected. Because such waste has high levels of potassium and organic matter in its chemical composition, as well as moderate amounts of nitrogen, it could represent an alternative to supply these nutrients in crop production, as have been reported by some research works, for instance, documenting an increase on the corn productivity in Acre State, Brazil [15].

However, some soils don't respond positively to the application of this sludge and there is risk on soil salinization due to the high sodium content (Table 1).

The disposal problem is aggravated because of the high content of chromium in the waste and efforts were made by the tannery for reducing it, which involved some modifications on the steps for leather production. Sample 2 was collected 
Table 4: $\quad$ Permissible concentration limits in effluents established by São Paulo State Register 997 published on 31 May 1976.

\begin{tabular}{|c|c|c|}
\hline PARAMETER & UNIT & VALUE \\
\hline $\mathrm{pH}$ & - & between 5 and 9 \\
\hline Temperature & ${ }^{\circ} \mathrm{C}$ & $<40$ \\
\hline Settleable solids & $\mathrm{mL} / \mathrm{L}$ & $<1$ \\
\hline Oil and grease & $\mathrm{mg} / \mathrm{L}$ & $<100$ \\
\hline $\mathrm{BOD}^{1}$ & $\mathrm{mg} / \mathrm{L}$ & $<60$ \\
\hline Arsenic & $\mathrm{mg} / \mathrm{L}$ & $<0.2$ \\
\hline Barium & $\mathrm{mg} / \mathrm{L}$ & $<5$ \\
\hline Boron & $\mathrm{mg} / \mathrm{L}$ & $<5$ \\
\hline Cadmium & $\mathrm{mg} / \mathrm{L}$ & $<0.2$ \\
\hline Lead & $\mathrm{mg} / \mathrm{L}$ & $<0.5$ \\
\hline Cyanide & $\mathrm{mg} / \mathrm{L}$ & $<0.2$ \\
\hline Copper & $\mathrm{mg} / \mathrm{L}$ & $<1$ \\
\hline Hexavalent chromium & $\mathrm{mg} / \mathrm{L}$ & $<0.1$ \\
\hline Total chromium & $\mathrm{mg} / \mathrm{L}$ & $<5$ \\
\hline Phenols & $\mathrm{mg} / \mathrm{L}$ & $<0.5$ \\
\hline Tin & $\mathrm{mg} / \mathrm{L}$ & $<4$ \\
\hline Soluble Iron $\left(\mathrm{Fe}^{2+}\right)$ & $\mathrm{mg} / \mathrm{L}$ & $<15$ \\
\hline Fluoride & $\mathrm{mg} / \mathrm{L}$ & $<10$ \\
\hline Soluble Manganese $\left(\mathrm{Mn}^{2+}\right)$ & $\mathrm{mg} / \mathrm{L}$ & $<1$ \\
\hline Mercury & $\mathrm{mg} / \mathrm{L}$ & $<0.01$ \\
\hline Nickel & $\mathrm{mg} / \mathrm{L}$ & $<2$ \\
\hline Silver & $\mathrm{mg} / \mathrm{L}$ & $<0.02$ \\
\hline Selenium & $\mathrm{mg} / \mathrm{L}$ & $<0.02$ \\
\hline Zinc & $\mathrm{mg} / \mathrm{L}$ & $<5$ \\
\hline
\end{tabular}

${ }^{1} \mathrm{BOD}=$ Biochemical Oxygen Demand $\left(5\right.$ days, $\left.20^{\circ} \mathrm{C}\right)$.

after the changes were introduced and the results indicate that despite some compounds like sodium and chromium had concentrations reduced in the sludge, this was not the case for others constituents like organic carbon, nitrate and potassium.

The results for the analyses of residuary waters utilized during the leather production by CURVASA tannery are given in Table 2. The data for Sample 1 were initially compared with guideline values established by two different legislations: Rule No. 12486 (NTA60) established in $20^{\text {th }}$ October 1978 by São Paulo State for defining the potable water standards (Table 3); Register 997 published on 31 May 1976 that defines the permissible concentration limits in effluents to be released to water bodies (coastal, fresh or ground waters) in São Paulo State (Table 4). It is possible verify that for some constituents in Sample 1 like sulfate, chloride, fluoride, zinc and chromium the guidelines values are exceeded. With the purpose of reducing their presence in the residuary waters, the tannery suspended the application of carbonates in the process and started the 
utilization of calcium oxide. Sample 2 was collected after the changes were introduced and the results indicated that the initiative caused reduction in all those constituents and others like sodium, potassium, calcium, magnesium, aluminum, titanium and bicarbonate. However, the nitrate concentration increased and the reduction was not enough to cause a chromium decrease up to a concentration level below $5 \mathrm{mg} / \mathrm{L}$, as allowed by São Paulo State Register 997 (Table 4).

Thus, the presence of several salts and metals in the residuary waters is not favorable for their direct disposal into the ground due to the possibility of groundwater contamination. This may be illustrated by the results of a study carried out inside the area of the Couro do Norte industry, located in the Icoaraci Industrial District (Belém-PA) [16]. The investigation covered the shallow subsurface and was performed in order to investigate the possibility of underground contamination by liquids used in the industrial processing of dead animal skin to produce tanned hide. The used geophysical methodology was: resistivity (imaging and vertical electric soundings), spontaneous potential, electromagnetic (slingram) and ground penetrating radar (GPR). The integrated geophysical interpretation of data indicated the underground flow direction and a shallow plume of contamination, caused probably by the disposal of effluents by the Couro do Norte industry.

In conclusion, the leather production is an activity with high environmental impact, but improvements may be achieved by tanneries, mainly in countries where the environmental legislation is not lax. To give an example of an efficient pollution prevention system, chromium loads per produced ton are generally abated from $8 \mathrm{~kg}$ to $1.5 \mathrm{~kg}$ [17]. VOC emissions are typically reduced from 30 $\mathrm{kg} / \mathrm{t}$ to $2 \mathrm{~kg} / \mathrm{t}$ in a properly managed facility [17]. Thus, the process remains highly polluting all the same. A review of the total pollution load decrease achievable according to the UNIDO [17] posts precise data on the abatement achievable through industrially proven low-waste advanced methods. It has been pointed out that [16] "even though the chrome pollution load can be decreased by $94 \%$ on introducing advanced technologies, the minimum residual load 0.15 $\mathrm{kg} / \mathrm{t}$ raw hide can still cause difficulties when using landfills and composting sludge from wastewater treatment on account of the regulations currently in force in some countries."

\section{Acknowledgement}

CNPq (National Council for Scientific and Technologic Development) in Brazil is thanked for partial financial support of this investigation.

\section{References}

[1] Uma potência chamada São Paulo; Portal do Governo do Estado de São Paulo, Online. www.saopaulo.sp.gov.br/saopaulo 
[2] Câmara setorial de leite e derivados apresenta radiografia da cadeia paulista; Secretaria de Agricultura e Abastecimento, Online. www.agricultura.sp.gov.br/ noticias2.asp?buscar $=$ leite e derivados $\& i d=1711$

[3] Secretário de Agricultura participa da Conferência Anual da OIE; Secretaria de Agricultura e Abastecimento, Online. www.agricultura.sp.gov.br/noticias2.asp?buscar=rebanho paulista\&id $=2161$

[4] Leather; Britannica, Online. http://www.britannica.com/EBchecked/topic/ 334079/leather

[5] Ganem, R.S., Curtumes: aspectos ambientais, Câmara dos Deputados: Brasília, 2007.

[6] Heidemann, E., Fundamentals of leather manufacture, Eduard Roether KG: Darmstadt, 1993.

[7] Bienkiewicz, K., Physical Chemistry of Leather Making, Robert E. Krieger Pub. Co.: Malabar, 1983.

[8] IFC (International Finance Corporation), Environmental, Health, and Safety Guidelines for Tanning and Leather Finishing, World Bank Group: Washington, 2007.

[9] Silva, R.B.G., Estudo hidroquímico e isotópico das águas subterrâneas do aqüifero Botucatu no Estado de São Paulo, Ph.D. Thesis, USP-São Paulo University: São Paulo,1983.

[10] Detalhes sobre Patrocínio Paulista; Prefeitura Municipal de Patrocínio Paulista, Online. http://www.patrociniopaulista.sp.gov.br/?link=principal\&s $=$ cidade

[11] Araújo, L.M., Franca, A.B. \& Potter, P.E., Hydrogeology of the Mercosul aquifer system in the Paraná and Chaco-Paraná Basins, South America, and comparison with the Navajo-Nugget aquifer system, USA. Hydrogeology Journal, 7, pp. 317-336, 1999.

[12] HACH, Water Analysis Handbook, 2 edn., Hach Company: Loveland, 1992.

[13] Boyd, C.E., Influence of organic matter on some characteristics of aquatic soils. Hydrobiologia, 36(1), pp. 17-21, 1970.

[14] APHA (American Public Health Association), Standard methods for the examination of water and wastewater. $17^{\text {th }}$ edn, Washington, 1989.

[15] Lodo de curtume: alternativa na recuperação de áreas degradadas; EMBRAPA Acre, Online. http://www.agronline.com.br/artigos/artigo.php? $\mathrm{id}=262$

[16] Nunes, L.P.M. \& Luiz, J.G., Caracterização geoelétrica de área de curtume localizada no distrito industrial de Icoaraci, Belém-PA. Revista Brasileira de Geofísica, 24 (4), pp. 467-481, 2006.

[17] Sahasranaman, A., Occupational safety and health in the tanning industry in South East Asia, UNIDO: Czech Republic, 2000. 